\title{
Japan: History and Culture from Classical to Cool
}

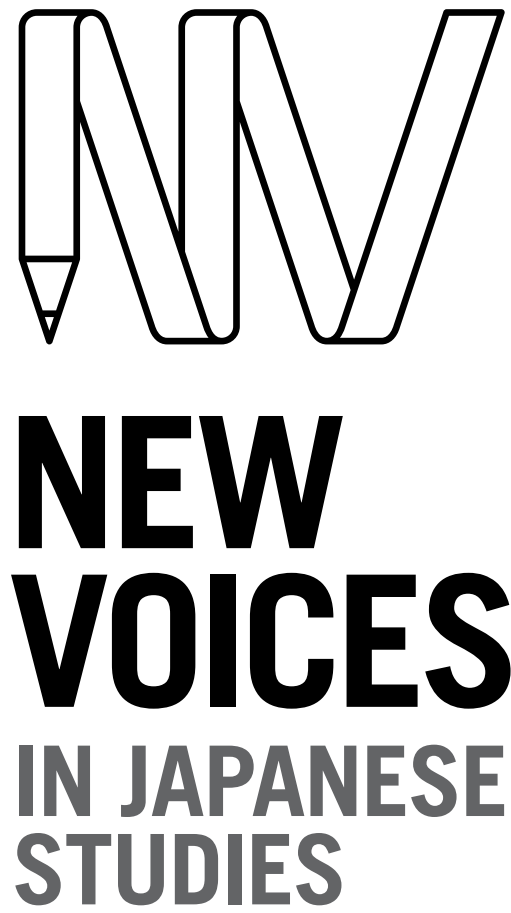

Reviewed by

Gwyn McClelland

Monash University

\section{KEYWORDS}

contemporary; culture; history; literature; Occupation; politics; popular culture; state; tradition; World War II

$\mathrm{N}$ ancy K. Stalker's Japan: History and Culture from Classical to Cool is a tertiary-level history textbook of Japan, bridging the premodern to modern periods. As a teacher of Japanese history, I know that finding a suitable textbook for the history teacher in the tertiary sector is not always easy. See, for example, Marius Jansen's The Making of Modern Japan (2000), or Hall's The Cambridge History of Japan (1991). The former is only concerned with modern Japan, focusing on politics and influencers, while the latter is in six volumes, making it inappropriate as a textbook. Whereas many history textbooks tend to treat culture, gender and aesthetics as an afterthought, the author of Japan: History and Culture asserts their integral importance to Japanese history (p. vii) - a perspective arguably in keeping with her expertise as Professor in Cultural and Gender Studies (20th Century) at the University of Hawaii. Her argument in this book is that by paying careful attention to the currents of literature, culture, religion, gender and art, the context and background for understanding Japanese history will come alive for students.

The chapters are arranged in largely chronological and thematic order, although there is some back and forth between periods. The book begins with a consideration of the early Japanese state and its origins, including Shinto

JAPANFOUNDATION 8 BRINGING JAPAN TO YOU

To link to this article: https://doi.org/10.21159/nvjs.11.r-02

\section{ISSN 2205-3166}

New Voices in Japanese Studies is an interdisciplinary, peer-reviewed journal showcasing the work of emerging scholars with ties to Australia or New Zealand and research interests in Japan.

All articles can be downloaded free at $\underline{\text { newvoices.org.au }}$

(C) The Japan Foundation, Sydney and Gwyn McClelland, 2019

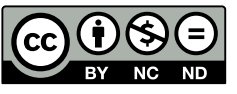

This work is licensed under a Creative Commons Attribution-NonCommercialNoDerivatives 4.0 International License. 
mythology and the Buddhist foundations of Japan. The author describes early influences from East Asia of Korean (Paekche) and Chinese origin, setting Japan's development in transregional and international context. Major historical events are examined in detail, including the development of the early centralised state, the 'rise of a warrior class,' and the period of political foment, unrest and civil war during the twelfth to fifteenth centuries which is characterised as 'disintegration and re-integration'. Stalker discusses how some religious movements were appropriated by the state for political gain, while other movements-such as those led by militant Buddhist lay believers and the monastic armies of the late sixteenth century (pp. 113-16)-were dissident and disruptive of the state. Dispersed through the historical discussions are analyses of culture, religion and society on subjects such as Noh drama (pp. 99-102), Zen movements (p. 167) and even 'Interior Architectural Décor' (p. 125). The latter, for example, is described in the chapter on 'Disintegration and Reunification' after a thorough and important discussion of the warring period. The integration of the cultural elements support and accompany vital discussions about war, power and politics, achieving the author's aim of providing useful and contextualised descriptions of 'aesthetics and tradition [which] occupy a central role in modern Japanese national identity' (p. vii).

Due to the wide range of subject matter covered, the discussion does not always progress chronologically. The Edo period, for example, is explored over two chapters, describing first the political climate of the Tokugawa Shogunate, and second how this period of relative peace across Japan resulted in the production of considerable cultural arts, drama and literature. In this way, the book shows how the political aspects of history are interwoven with the arts and literature, and vice versa. As a result, some of Chapter 7 reads as a critique of Japanese literature rather than as a history textbook. This approach is innovative and the discussion of poets, authors and important literary movements lends itself well to class discussions and may also assist students in gaining a better understanding of the period under study. One example is how the work, life and travels of Matsuo Bashō, a significant poet and teacher of the Tokugawa era, is described at some length (pp. 184-186), giving insight into the environment and socio-cultural context of Edo Japan.

The book considers the history and culture of twentieth-century (and finally twenty-first century) Japan over the final four chapters. Topics considered in this section range from Marxism to the board game suguroku, department stores and an introduction to the feminist writer, Raicho Hiratsuka. Stalker usefully contextualises the twentieth-century experience of war and militarisation, from Japan's colonial conquests and the military comfort women system instituted during World War II to the occupation of Korea, Taiwan and multiple Pacific islands. The final chapter is titled 'Cool Japan as Cultural Superpower', and reviews economic development, social issues and gender concerns in modern Japan (1980 to present). Stalker includes here varied elements of 'Cool Japan' such as literature (Haruki Murakami), anime, cosplay, kyara, J-pop and food.

Another notable aspect of the book is its acknowledgement of lesser known (but nonetheless important) voices and movements through the ages. Japan 
historians' tendency to focus on the 'great men of history' should be subverted, especially in our classrooms. This textbook goes some way to balancing the record, picking up on significant female contributions to politics, society and literature and by noting the situations of minority groups such as burakumin, Ainu and wider mass culture, as opposed to focusing solely on powerbrokers and elites. Perhaps one shortcoming of the book is an over-reliance on EuroAmerican-centric Japanese Studies texts. It would also have been helpful for those with Japanese language ability to have Japanese-language sources included in the resource lists at the end of each chapter.

Japan: History and Culture is an entertaining and concise textbook for university undergraduate and postgraduate history teachers or senior high school students. A particularly practical feature of this book is that each chapter ends with a postscript of further recommended reading and films which assists the teacher (and student) in exploring related visual and supplementary resources. Aside from being useful in class, this book will also be a helpful reference for academics to support astute teaching, writing and lecturing.

\section{REFERENCES}

Hall, J. W. 1991. The Cambridge History of Japan. 6 vols. Cambridge: Cambridge University Press.

Jansen, M. B. 2002. The Making of Modern Japan. Cambridge, Mass.: Belknap Press.

\section{REVIEW}

